\title{
PERANCANGAN RANGKA BODY MOBIL BUGGY UNTUK SATU ORANG PENUMPANG
}

\author{
Edison $^{1}$.Delwita ${ }^{2}$ \\ DosenJurusan Teknik Mesin ITP - Fakultas Teknologi Industri ITP ${ }^{1,2}$. \\ edison_1961@yahoo.com ${ }^{1}$ \\ DOI: http://dx.doi.org/10.31869/rtj.v2i2.1433
}

\begin{abstract}
Abstrak:Mobil buggy merupakan salah satu jenis dari mobil yang dirancang sesuai dengan kebutuhan kendaraan pariwisata. Kendaraan yang diperuntukan untuk anak-anak usia 8-15 tahun dengan berat badan maksimum $75 \mathrm{~kg}$, Kapasitas yang dimiliki hanya mampu membawa satu orang penumpang (single seater). Penelitian ini bertujuan untuk merancang dan menganalisis kekuatan rangka pada penumpang dengan beban $75 \mathrm{~kg}$ menggunakan software autodesk inventor, dengan menggunakan fitur stress analysis yang dilengkapi dengan metode finite element analysis (FEA). Dapat diketahui luaran berupa von misses stress, displacement, dan safety factor. Rangka hasil rancangan berdiameter 1 inchi, material mild steel.
\end{abstract}

Kata kunci : perencanaan, rangka, von misses stress, displacement, safety factor

\section{PENDAHULUAN}

Seiring dengan perkembangan zaman semakin maju dibidang industri banyak perusahaan yang membutuhkan kendaraan untuk usahanya yang dapat digunakan sebagai alat transportasi pada lingkungan perusahaan, seperti perusahaan yang bekerja dikehutanan, pertanian, area perindustrian dan sebagainya. supaya dapat menunjang kebutuhan tersebut dibutuhkan biaya yang sangat besar untuk pengadaan fasilitas perusahaan. Untuk mengurangi biaya pada perusahaan, ada satu alternatif yang dapat mengatasi masalah transportasi pada lingkungan kerja yaitu mobil buggy. Mobil buggy dengan dimensi yang cukup kecil dapat mengatasi masalah transportasi pada lingkungan kerja perusahaan.

Istilah buggy hampir pasti mewakili kendaraan off-road dan kendaraan off-road buggy yang bersifat rekreasi. Meskipun turunannya berbeda namun ada kesamaan penting yakni mobil buggy berakar dari kendaraan home made atau buatan sendiri dan dibuat khusus untuk medan tertentu.

Mobil buggy merupakan salah satu kendaraan yang jarang digunakan masyarakat umum. Kendaraan yang ditumpangi satu sampai empat orang penumpang itu kebanyakkan digunakan didaerah padang pasir, perkebunan atau tempat wisata bahkan bisa juga pada daerah pegunungan yang berlumpur .umumnya mobil buggy dirancang khusus untuk kendaraan operasional diwahana outdoor, mobil jenis ini biasanya memiliki spek yang disesuaikan dengan ketangguhan untuk melahap medan off-road. Kendaraan ini juga dapat digunakan untuk bersantai, berolahraga, sebagai fasilitas kerja dan sebagainya.

\section{TINJAUAN PUSTAKA}

Mobil buggy merupakan salah satu kendaraan terbuka yang biasa digunakan pada daerah gurun pasir. Dengan seiring perkembangan otomotif mobil buggy sekarang dapat digunakan pada daerah yang berlumpur, dengan demikian bila suatu kendaraan dapat digunakan diberbagai situasi jalan maka mobil tersebut adalah mobil serbaguna yang dapat digunakan dimana saja. Dengan kesederhanaan rangka dan memiliki dimensi yang cukup kecil maka mobil buggy juga dapat digunakan diberbagai situasi seperti, sebagai kendaraan pada kawasan pariwisata, sebagai kendaraan yang bisa dikompetisikan. Bahkan dengan perkembangan terus menerus mobil buggy juga dapat dijadikan alat transportasi pada lingkungan kerja.

Perencanaan produksi suatu produk merupakan bagian yang sangat besar dan sangat menentukan kualitas produk. Perencanaan merupakan kegiatan awal dari rangkaian kegiatan sampai ke proses pembuatan produk sehingga dalam tahap ini juga ditentukan apa yang harus dilakukan dan bagaimana cara melakukannya termasuk merencanakan tahapan pembuatan produk agar mendapatkan kualitas yang bagus, apabila pada tahap perencanaan sudah ditentukan kemudian dilanjutkan ketahap perancangan dimana pada tahap perancangan akan dimulai eksplorasi bentuk desain.

$\begin{array}{lr}\text { Fakultas Teknik UMSB } & \text { ISSN 2599-2081 } \\ \text { EISSN 2599-2090 }\end{array}$




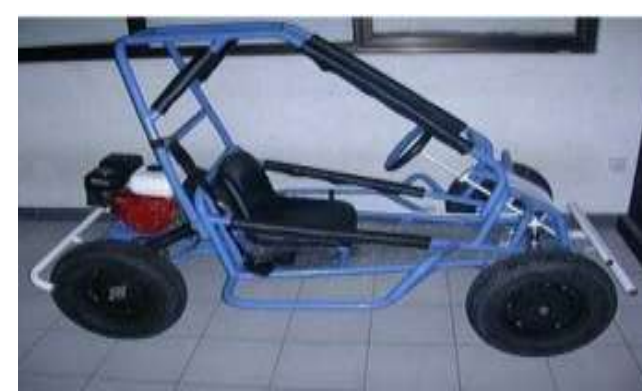

Gambar 1. Bentuk umum mobil buggy.

\section{METODOLOGI PENELITIAN}

Metode penelitian yang memberikan arah bagi pelaksana penelitian sehingga data yang diperlukan dapat terkumpul. Penelitian ini menggunakan metode penelitian dan pengembangan dengan bantuan perangkat lunak (software) yang mampu menganalisis karakteristik statik suatu model. Metode penelitian dan pengembangan adalah metode penelitian yang digunakan untuk menghasilkan sebuah perencanaan dimana perencanaan tersebut mengetahui sebuah rancangan yang akan diuji. Khusus dalam penelitian ini perencanaan rangka body mobil buggy sebagai objek penelitian dengan menekan kan pada subjek analisis pada material dan beban penumpang $75 \mathrm{~kg}$ menggunakan software engineering $\mathrm{CAD}$. Pembangkitan kejadian ini atau keadaan ini berupa pembebanan yang berasal dari beban penumpang.

Material atau bahan yang dipakai pada rangka body mobil buggy satu penumpang ini adalah mild steel atau plain carbon steel. Standar america menyatakan bahwa carbon steel memiliki kandungan karbon tidak lebih dari 2\% dan tanpa campuran bahan lain yang berarti. Produksi ini memiliki pasar paling tinggi dan dipergunakan untuk berbagai aplikasi.

\section{Bahan Penelitian:}

1. Laptop/PC

2. Aplikasi Autodesk Inventor

\section{Prosedur Penelitian:}

1. Persiapkan Autodesk Inventor.

2. Buka aplikasi autodesk inventor untuk men-desaign rancangan alat.

3. Analisis bagian rangka pada beban penumpang.

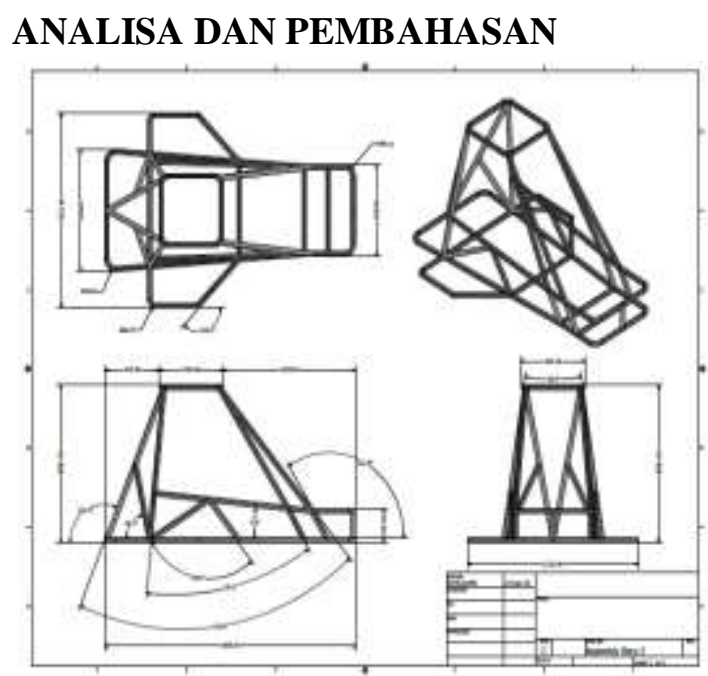

Gambar 2. Ukuran rangka mobil buggy

Gaya Momen pada Poros

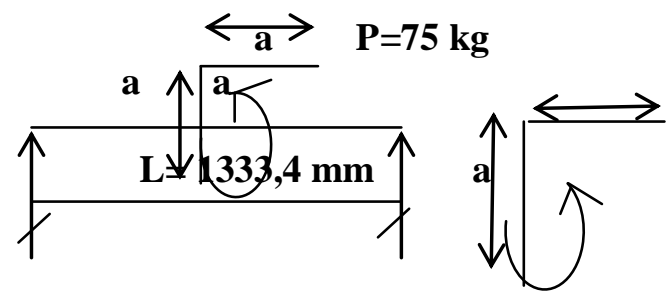

Gambar 3.Free Body Diagram

$$
\begin{aligned}
& \mathbf{P a}=p \cdot \frac{\boldsymbol{L}}{2} \\
& =75 \mathrm{~kg} \cdot \frac{1333,4 \mathrm{~mm}}{2}
\end{aligned}
$$

$$
=75 \mathrm{~kg} .666,7 \mathrm{~mm}
$$

$=50002,5 \mathrm{~kg} . \mathrm{mm}$

\section{Pembebanan pada Rangka}

Simulasi analisis rangka mobil buggy beban penumpang sebesar $75 \mathrm{~kg}$ menggunakan software autodesk inventor. Menentukan constraint dengan acuan yang ada pada produk desain yang telah dimodelkan. Sedangkan beban atau berat penumpang dibuat sebesar 75 $\mathrm{kg}$. Berikut tampilan hasil simulasi-simulasi pada beban maksimal yaitu pada berat penumpang $75 \mathrm{~kg}$. 


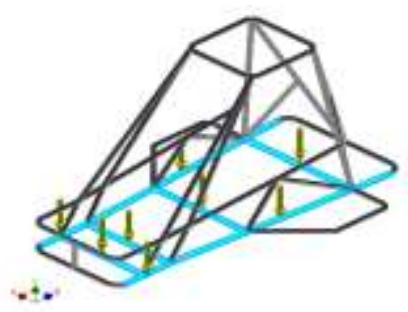

Gambar 3. Pemberian Beban Pada Rangka Mobil Buggy

Setelah ini dapat hasil simulasisimulasi tersebut terdapat hasil sebagai berikut berupa von misses stress, $1^{\text {st }}$ principal stress, $3^{\text {rd }}$ principal stress, displacement dan safety factor.

\begin{tabular}{|c|c|c|}
\hline Nama & \multicolumn{2}{|c|}{ Steel, Mild } \\
\hline \multirow{4}{*}{ General } & Mass Density & $\begin{array}{c}7,85 \\
\mathrm{~g} / \mathrm{cm}^{3}\end{array}$ \\
\cline { 2 - 3 } & Yield & $207 \mathrm{Mpa}$ \\
\cline { 2 - 3 } & Strength & \\
\cline { 2 - 3 } & Ultimate & $345 \mathrm{Mpa}$ \\
& Tensile & \\
\hline \multirow{5}{*}{ Stress } & Strength & \\
& Young & $220 \mathrm{Gpa}$ \\
& Modulus & \\
\cline { 2 - 3 } & Poissons & $0,275 \mathrm{ul}$ \\
& Ratio & \\
\cline { 2 - 3 } & Shear & 86,2745 \\
& Modulus & $\mathrm{Gpa}$ \\
\hline
\end{tabular}

Tabel 1. Data material rangka bodi nobil buggy

\section{Faktor Keamanan (Faktor Of Safety/FOS/SF)}

Safety faktor atau angka keamanan merupakan salah satu parameter penting untuk menentukan apakah suatu kontruksi itu aman atau tidak. Safety faktor merupakan perbandingan antara tegangan yang terjadi. Kontruksi dinyatakan aman apabila keamanannya diatas nol. Nilai FOS menunjukkan angka sebesar 15.

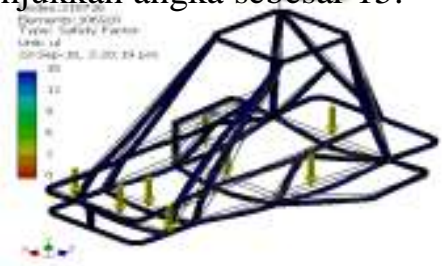

Gambar 4. Tampilan Safety Factor saat Beban Penumpang $75 \mathrm{~kg}$

\begin{tabular}{|c|c|c|}
\hline Nama & Minimum & $\begin{array}{c}\text { Maximu } \\
\mathrm{m}\end{array}$ \\
\hline Volume & \multicolumn{2}{|c|}{$8791310 \mathrm{~mm}^{3}$} \\
\hline Mass & \multicolumn{2}{|c|}{$69,0118 \mathrm{~kg}$} \\
\hline $\begin{array}{c}\text { Von misses } \\
\text { stress }\end{array}$ & $\begin{array}{c}0,0000007064 \\
26\end{array}$ & $\begin{array}{c}12,6884 \\
\mathrm{Mpa}\end{array}$ \\
\hline $\begin{array}{c}\text { 1st } \\
\text { principal } \\
\text { stress }\end{array}$ & $\begin{array}{c}-0,725984 \\
\mathrm{Mpa}\end{array}$ & $\begin{array}{c}13,5135 \\
\text { Mpa }\end{array}$ \\
\hline $\begin{array}{c}\text { 3rd } \\
\text { principal } \\
\text { stress }\end{array}$ & $-7,93816 \mathrm{Mpa}$ & $\begin{array}{c}1,6504 \\
\mathrm{Mpa}\end{array}$ \\
\hline $\begin{array}{c}\text { Displaceme } \\
\mathrm{nt}\end{array}$ & $0 \mathrm{~mm}$ & $\begin{array}{c}0,049358 \\
6 \mathrm{~mm}\end{array}$ \\
\hline $\begin{array}{l}\text { Safety } \\
\text { factor }\end{array}$ & $15 \mathrm{ul}$ & $15 \mathrm{ul}$ \\
\hline
\end{tabular}

Tabel 2. Rekapitulasi Simulasi Kontruksi Frame

\section{Von Misses Stress}

Tegangan salah satu post proccesor adalah hasil perhitungan hubungan tegangan regangan pada model benda, regangan diperoleh dari deformasi yang dialami model. Tegangan ekivalen yang digunakan metode von misses.

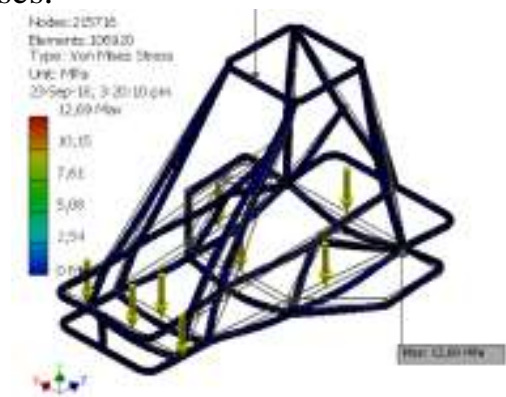

Gambar 5. Tampilan equifalent stress dengan beban $75 \mathrm{~kg}$

Tegangan ekivalen maksimum terjadi dibagian las rangka belakang sebesar 12,69 Mpa, kemudian tagangan ekivalen minimum sebesar 0 Mpa.

\section{Displacement}

Hasil utama dari analisis struktur statis menggunakan metode elemen adalah deformation atau displacement. Berikut ini ilustrasi hasil analisis total deformation pada model. Hasil simulasi menunjukkan bahwa total deformation terbesar ada pada rangka bawah tempat penyangga duduk penumpang sebesar $0,04936 \mathrm{~mm}$ dan total deformation 
terkecil ada pada bagian atas rangka penumpang yaitu sebesar $0 \mathrm{~mm}$.

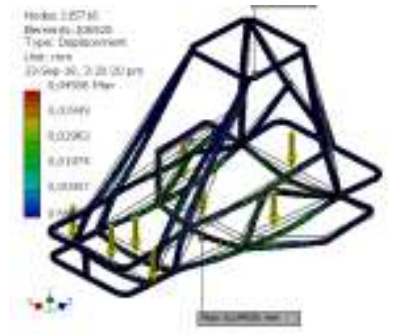

Gambar 6. Tampilan Displacement

\section{PENUTUP}

Dari hasil simulasi analisis rangka mobil buggy satu penumpang dengan berat $75 \mathrm{~kg}$ menggukan software autodesk inventor diperoleh kesimpulan sebagai berikut:

1. Factor of safety dari hasil simulasi $=15$ ul

2. Equivalent stress dari hasil simulasi $=$ $12,69 \mathrm{Mpa}$

3. Total deformation dari hasil simulasi $=$ $0,04936 \mathrm{~mm}$

Saran yang dapat diambil dari hasil perencanaan rangka bodi mobil buggysatu penumpang adalah :

1. Untuk pengembangan lebih lanjut, akan lebih baik dilakukan analisa kekuatan rangka pada kondisi beban dinamik.

2. Berdasarkan hasil perencanaan rangka body mobil buggy satu penumpang disarankan pada peneliti yang akan melakukan penelitian yang sama atau pengembangan terhadap perencanaan ini dapat melakukan modifikasi kepada komponen-kompoenen yang memiliki angka keamanan yang sangat tinggi dalam upaya untuk meningkatkan efesiensi bahan.

\section{DAFTAR PUSTAKA}

Rizayana, farid., (2004), desain dan pembuatan prototipe light buggy.teknik mesin universitas pasundan.

Siregar, fachruddin., (2007), pembuatan dan assembly komponen mobil buugy untuk satu penumpang.

Sadikin, ali., (2013), perancangan rangka chasismobil listrik untuk 4 penumpang menggunakan software 3D siemens NX8. Teknik mesin universitas negri semarang.
Amin, fuada dan fauzi, A (2013), rancang bangun mesin pemipil jagung dan penghancur bonggol jagung tenaga surya ramah lingkungan.

Sandhy, M, novian dan rahmawaty (2013), perancangan sasis mobil dan analisa pembebanan statik menggunakan perangkat lunak ansys 14.0. teknik mesin, sekolah tinggi teknik harapan.

Setyono, B., Mrihrenaningtyas dan hamid, A (2016), Perancangan analisis kekuatan frame sepeda hibrid "trisona" menggunakan software autodesk inventor.

Setyono, B dan gunawan, S (2015), perancangan dan analisis chassis mobil listrik " semut abang" menggunakan software autodesk inventor pro 2013, seminar nasional sains dan teknologi tarapan III 2015 ISBN 978-98569-1-0.

Yamin, satyadarma dan hasanudin, A. (2008), analisis tegangan pada rangka mobil boogie 